\title{
TRANSLATORS THROUGH HISTORY
}

\author{
John Robert Schmitz *
}

DELISLE, Jean and WOODSWORTH, Judith (eds.) (1995) Translators through History. Amsterdam, John Benjamins Publishing Company and Unesco Publishing, 345pp + xvi.

Translators through History is indeed an ode to translation and to the work of translators. This publication is a recent addition to the John Benjamins Translation Library published jointly with Unesco and produced under the auspices of the International Federation of Translators (FIT). Delisle and Woodsworth have organized an excellent collection of nine articles written by renowned specialists in the field of translation. The book contains two appendices. The first, provides, in some detail, information about the twenty-four illustrations that accompany this book. Illustrations are necessary in a work devoted to the history of translation. The reader will encounter respectively photographs of "the patriarch of translators", Yehudah ibn Tibon (1120-90), of Étienne Dolet (1509-46), who introduced the words traduction and traducteur into French, and of Constance Garnet (1861-1946), who translated the Russian novelists Tolstoy, Dostoyevsky and Turgenev into English for the reading public in Britain, Australia, and North-America.

The second appendix lists the names of the many authors who contributed to the nine chapters or who translated specific chapters as well as those who acted as proofreaders of the volume. It would have been useful to include brief biographic information about the contributors and the translators, especially for newcomers to the field of translation and for the benefit of specialists from other areas.

Each of the nine articles presents a detailed bibliography and all the sources cited in the various papers are collected in a special section entitled "Works Cited" (pp. 295-333). Each chap-

(*) Universidade de Campinas, Brazil 
ter contains a very useful section called "further reading" and the references cited therein are also found in the general bibliography. Another useful feature of this publication, particularly important in a work devoted to the history of a specific field, is the final section (pp. 327-345) that contains the names of all the individuals cited in the various papers who contributed to the history of translation.

Translators through History fills a gap in the bibliography of translation studies for there have been relatively few publications devoted to the history of the field. This book is a complement to L.G. Kelly's The True Interpreter: A History of Translation Theory and Practice in the West for this author tends to emphasize theory and practice in the history of translation while Delisle and Woodsworth's collection of papers stresses the political, cultural, economic and social factors that have shaped the history of translation in the West.

Those readers who decide to devote their time and energy to reading this publication will not be at all disappointed. While there is a great deal of factual information in each article, the content of the papers is indeed fascinating. The role of translation in the history of ideas, in the development of science and culture is emphasized by all the authors who have participated in the writing of the volume.

The first three chapters of this volume deal respectively with the role of translation and the invention of alphabets, the development of national languages and the emergence of national literatures. The work of Cyril and Methodius in the development of an alphabet for the Slavic languages, the work of Martin Luther in the establishment of a norm for Modern German, the endeavors of Jorge Luis Borges in forging Argentine literature are concrete examples of the pervasiveness of translation in intellectual history and the development of ideas.

The authors of "Translation and the Emergence of National Literatures" (Chapter 3) point to the work of Geoffrey Chaucer (ca. 1340-1400) who viewed translation as re-creation and perceived "... an overlap between translation, compilation, rewriting and original authorship" (p. 67). The authors point out that Chaucer's view of translation was held by many different trans- 
lators and remained "a common thread throughout history". But during certain periods of history, the view of the supremacy of the original author prevailed. The authors make an important point for a hasty reading of some of the deconstructionalist literature could lead to the belief that all translators at all times (my emphasis) were wedded to the sacredness and superiority of the original source language version.

In Chapter 4, "Translators and the Dissemination of Knowledge", the authors point to the efforts of numerous translators who contributed to breaking down the cultural isolation of the Nordic countries from the rest of Europe by translating into major European languages the works of Hans Christian Andersen, Søren Kierkegaard, Henrik Ibsen and August Strindberg.

Chapter 5, "Translators and the Reins of Power", is important for the authors observe that translators were not always subservient or beholden to the original. Translators in fascist Italy and in the former Soviet Union succeeded in importing values and ideas that clashed respectively with Fascist and Marxist ideologies.

Not all translators revered the original or considered the original author to be a god-like figure. The authors of this chapter refer to the view of translation held by Nicolas Perrot d'Ablancourt (1606-64), who " ... advocated censorship, additions, modifications or modernization of the original text..." (p. 143). D'Ablancourt wanted to do more than translate. His desire was to create and mold new forms in his native French.

Those who read this chapter will probably be comforted to know that not all translators were poorly remunerated for their services. King Alfonso X of Spain and King Charles V of France were quite generous in providing funds for translators.

This chapter also includes information about the role of women and their power struggle with men in the work of translation. The authors cite Margaret Tyler as an exception to the view set out for women for she translated a Spanish novel of chivalry, A Mirrour of Princely deedes and Knighthood “... in a nonliteral manner and prefaced it with a vigorous text in which she defended her work and introduced positive images of women in actions, at a time in England when it was not considered seemly for women to be active." (p. 150) 
Chapter 6 "Translators and the Spread of Religions" is indeed a storehouse of information about the role of translators in disseminating the sacred texts of Judaism, Christianity, Islam, Hinduism and Buddhism and in the spread of some of these religions in different parts of the world. Perhaps not all Bible translators are aware that Elizabeth Cady Stanton (1815-1902) published a Woman's Bible in 1898 along with a commentary to correct the "masculinist" bias of earlier versions.

The authors of Chapter 7, entitled "Translators and the Transmission of Cultural Values", present examples of how translation contributes to the exchange of cultural values in their reference to the work of the French Huguenot, Pierre Coste (16681747), who worked in two directions. On one hand, he translated the works of Racine and Montaigne for English readers, and on the other, translated John Locke's An Essay Concerning Human Understanding to French. Coste's translation of Locke introduced this eminent English philosopher's ideas to Continental Europe.

Another example closer the present time is the work of various French translators (Boris Vian, Raymond Queneau and Michele Pilotin) who introduced a new genre - American science fiction literature - to French readers. The authors of this paper state that one of the main functions of translation is:

... to redistribute certain elements geographically; as source texts and some of their features are handled in different ways by translators, they are cast into a wide range of sociocultural contexts. Translations imported and domesticated in this way can influence target-culture ideals and models. Something dormant in one culture can flourish once it is transplantedthrough translation- to more fertile ground or a more favorable climate in another culture. Once strengthened in the target culture, the new models can then return to enrich the original source culture. (p. 218)

The words cited above are important for they indicate the role of translation in intellectual exchange. Translation is not merely "taking" or "giving" but can and does involve the "returning" of ideas.

TradTerm, 4(1), $1^{\circ}$ semestre de 1997 , p. 203-208 
In the article devoted to "Translators and the writing of dictionaries" (Chapter 8), prospective readers are informed that two distinguished authors of dictionaries, Émile Littré and Samuel Johnson, were also translators. This Chapter is essential reading for not every publication in the field of translation points to the contribution of lexicography/lexicology and its intimate relationship with translation studies.

Chapter 9, "Interpreters and the Making of History", describes the work of great conference and escort interpreters. Worthy of note is the contribution of Léon Dostert (1904-1971) who was responsible for the interpreting and translation at the Nuremburg trials at the end of World War II.

Lawrence Venuti argues that the work of translators is often invisible and translators themselves are "invisible" for their names are, in some cases, omitted and, in other cases, their names are given little or no prominence in the specific translations and also in the distribution of advertising credits. A major contribution of Delisle and Woodsworth's Translators Through History is to make the work of translators visible to specialists outside (my emphasis) the field of translation as well as to provide a source of information for practicing translators and teachers of translation in order to make the work of translators "visible" to their own students. This book will be indeed useful for upper level undergraduate courses and, of course, essential reading for graduate seminars. A thorough reading of each chapter will, no doubt, inspire further research in the form of seminar papers, articles, theses and dissertations dealing with translation and the specific themes covered: (i) the development of alphabets, national languages and literatures and the writing of dictionaries, (ii) dissemination of knowledge and the use of power, (iii) the spread of religions and transmission of cultural values, (iv) the history of the contribution of interpreters and the exchange of ideas.

There are few problems in the proofreading ("the twentieth century was been a time when...", p. 132) but they do not mar this stimulating and important book. To be fair to the editors, it is not an easy endeavor to put together a text of nine papers written by many different hands. For example, Chapter 5 
"Translators and the Reins of Power" was prepared by nine different authors.

Translation is truly an international endeavor and the proof of this statement can be observed in the international flavor of the volume. Nearly fifty specialists in translation from twenty different countries participated in the elaboration of this book. The editors are to be commended for their efforts. Every discipline needs to examine its history and translation is no exception. 